\title{
Kendala mahasiswa dalam identifikasi dan asesmen anak dengan gangguan emosi dan perilaku selama pandemi COVID-19
}

\author{
Wening Prabawati ${ }^{1 *}$, Aini Mahabbati ${ }^{2}$ \\ ${ }^{1}$ Universitas Negeri Yogyakarta, Yogyakarta, Indonesia. \\ ${ }^{2}$ Universitas Negeri Yogyakarta, Yogyakarta, Indonesia. \\ *Coresponding Author. Email: weningprabawati@uny.ac.id, Telp: +6281225911175
}

\begin{abstract}
Abstrak: Identifikasi dan asesmen anak dengan gangguan emosi dan perilaku atau emotional and behavior disorders (EBD) merupakan tahapan awal dalam menentukan layanan pendidikan yang sesuai bagi anak dengan EBD. Tujuan penelitian ini yakni mengetahui apakah mehasiswa mengalami kendala selama melakukan identifikasi dan asesmen anak dengan EBD selama pandemi Covid-19. Jenis penelitian ini yakni penelitian studi kasus. Subjek penelitian ini yakni delapan orang mahasiswa semester enam. Teknik pengumpulan data yakni obervasi, wawancara, dan dokumentasi. Analisis data yang digunakan yakni analisis deskriptif. Hasil penelitian menunjukkan bahwa mahasiswa mengalami kendala selama mengumpulkan data-data yang digunakan untuk identifikasi dan asesmen pada anak dengan EBD selama pembelajaran daring. Kendala yang dialami mahasiswa yakni kesulitan dalam menghubungi sumber seperti guru dan orang tua, tidak bisa bertemu dengan anak secara langsung, data yang diperoleh terbatas. Terdapat tinjauan pustaka untuk meminimalisir kendala yang ada seperti penggunaan teknologi dan adanya koneksi emosional. Kesimpulan penelitian yakni adanya kendala yang dialami mahasiswa sehingga menghambat mahasiswa dalam melakukan identifikasi dan asesmen pada anak dengan EBD selama pandemi Covid-19.
\end{abstract}

Kata kunci: kendala, identifikasi dan asesmen, anak dengan gangguan emosi dan perilaku, pandemi Covid-19

\section{Student's obstacles in identification and assessment of children with emotional and behavior disorders during the COVID-19 pandemic}

\begin{abstract}
Identification and assessment of children with emotional and behavior disorders (EBD) are the first steps in determining appropriate educational services for children with EBD. The purpose of this study is to find out whether students experience problems during identification and assessment of children with EBD during the covid-19 pandemic. This type of research is a case study research. The subjects of this study were eight sixth semester students. Data collection techniques are observation, interviews, and documentation. The data analysis used is descriptive analysis. The results showed that students experienced problems while collecting data used for identification and assessment of children with EBD during online learning. The obstacles experienced by students were difficulties in contacting sources such as teachers and parents, not being able to meet children directly, and the data obtained was limited. There is a literature review to minimize existing obstacles such as the use of technology and the existence of emotional connections. The conclusion of the study is that there are obstacles experienced by students that prevent students from identifying and assessing children with EBD during the covid-19 pandemic
\end{abstract}

Keywords: obstacles, identification and assessment, children with emotional and behavior disorders, Covid-19 pandemic

\section{PENDAHULUAN}

Layanan pendidikan bagi anak dengan gangguan emosi dan perilaku atau emotional and behavior disorders (EBD) terdiri dari pembelajaran akademik dan penanganan perilaku bermasalah. Layanan pendidikan tersebut akan sesuai dengan kondisi anak apabila didasarkan pada hasil identifikasi dan asesmen. Identifikasi dan asesmen pada anak dengan EBD merupakan tahapan awal untuk mengenali kondisi anak, baik dari kemampuan, kendala, sampai dengan bakat dan minat anak. Selain itu, pada anak dengan EBD, asesment juga bagian penting dalam memberikan dukungan untuk perilaku positif yang biasa disebut dengan functional behavior assessment (Kirk, Gallagher, Coleman, \& Anastasiow, 2009). 
Terkadang, identifikasi dan asesment dimaknai sama dengan testing atau pengujian. Padahal, identifikasi dan asesment serta testing merupakan dua hal yang berbeda. Testing merupakan proses tes penilaian yang bisa menjadi bagian dari identifikasi dan asesment. Sedangkan identifikasi dan asesmen digunakan untuk mengumpulkan informasi mengenai masalah atau isu tertentu yang dapat dijadikan sarana untuk mencapai tujuan dan membantu untuk memecahkan masalah (Whitcomb, 2018). Identifikasi pada anak dengan EBD digunakan untuk menduga atau mengetahui masalah perilaku yang dimiliki anak dari aspek intensitas, pola, dan durasi. Selain itu, identifikasi pada anak dengan EBD juga berguna sebagai referensi dalam menunjukkan jenis dukungan di sekolah, di rumah, atau keduanya (Zionts, Zionts, \& Simpson, 2002). Sedangkan asesmen, berguna bagi pendidik terutama ketika akan mempersiapkan pembelajaran bagi anak dengan EBD. Data yang diperoleh melalui asesmen memberi tahu pendidik mengenai kondisi peserta didik dengan EBD, pengetahuan yang diketahui oleh peserta didik, dan kemampuan yang dimiliki dan perlu dipelajari oleh peserta didik (Kauffman \& Landrum, Characteristics of Emotional and Behavioral Disorders of Children and Youth: Eleventh Edition, 2018).

Ada beberapa penelitian yang membahas mengenai identifikasi dan asesmen pada anak dengan EBD. Pertama, penelitian yang dilakukan oleh Xurvein (2015) menunjukkan bahwa asesmen yang dilakukan oleh tim multidisiplin akan memberikan hasil yang lebih optimal. Tim akan memperoleh data yang lebih luas dan bisa melihat kondisi anak dengan EBD dari berbagai sudut pandang. Proses asesmen juga membantu dalam memperhatikan semua aspek dan kebutuhan dari anak dengan EBD (Xurvein, 2015). Kedua, penelitian yang dilakukan oleh Gage \& Lierheimer (2012) menunjukkan bahwa peserta didik dengan EBD memiliki konsep diri yang tinggi dan konsep diri tersebut dipengaruhi oleh etnis dan urbanitas. Data terkait dengan konsep diri pada anak dengn EBD bisa diperoleh melalui identifikasi dan asesmen. Identifikasi dan asesmen ini berguna terutama untuk memberikan intervensi dan program yang sesuai dengan kebutuhan sosial dan emocional pada anak dengan EBD (Gage \& Lierheimer, 2012). Ketiga, penelitian yang dilakukan oleh Syamsi (2016) menunjukkan bahwa asesmen dilakukan dengan adanya pemahaman dan ketekunan dalam mengamati sasaran dari asesmen. Kegiatan asesmen dapat membantu dalam mengumpulkan data terkait perilaku sosial di lingkungan keluarga, sekolah, masyarakat, serta perilaku dalam berkoordinasi dan pembelajaran. Asesmen dilakukan dengan menggunakan alat/instrumen yang berkaitan dengan sasaran asesmen, seperti alat untuk mengukur sensori perabaab, pengecapan, bina diri, simbol bilangan, serta perceptual motor. Asesmen juga memerlukan ruang khusus untuk dan dilakukan oleh tim multidisiplin (Syamsi, 2016).

Akan tetapi, adanya pandemi Covid-19 saat ini memberikan dampak dalam pelaksanaan identifikasi dan asesmen pada anak dengan EBD. Pada mata kuliah pendidikan ortodidiaktik anak dengan EBD terdapat kegiatan berupa identifikasi dan asesmen pada subjek dengan EBD di lapangan. Mahasiswa mengalami kendala karena adanya protokol kesehatan salah satunya untuk menjaga jarak dan tidak berkerumum. Hal tersebut membatasi mahasiswa untuk bisa berinteraksi baik dengan subjek ataupun dengan narasumber lainnya yang membantu dalam mengumpulkan data anak dengan EBD. Kondisi tersebut akhirnya berdampak pada hasil yang diperoleh oleh mahasiswa juga menjadi kurang maksimal. Hasil tersebut juga berpengaruh pada kegiatan-kegiatan perkuliahan lainnya, yang dilaksanakan menggunakan data dari identifikasi dan asesmen, seperti menentukan program pembelajaran, metode, materi, media, sampai dengan bentuk evaluasi yang sesuai dengan kondisi anak dengan EBD. Oleh karena itu, penelitian ini mencoba untuk mencari tahu, bentuk-bentuk kendala yang dihadapi oleh mahasiswa selama melakukan identifikasi dan asesmen pada anak dengan EBD selama pandemi Covid-19. Harapannya, adanya kendala dalam melaksanakan identifikasi dan asesmen dapat memberikan gambaran mengenai kondisi terkini dan bisa mencarikan solusi untuk mengatasi permasalahan tersebut.

\section{METODE}

Jenis penelitian yang digunakan yakni studi kasus kegiatan mahasiswa dalam melakukan identifikasi dan asesmen pada individu dengan hambatan emosi dan perilaku di masa pandemi Covid19. Sebelumnya, pelaksanaan identifikasi dan asesmen oleh mahasiswa dengan cara bertemu langsung dengan anak dengan hambatan emosi dan perilaku, guru, atau keluarganya. Akan tetapi selama pandemi Covid-19, mahasiswa terbatas dalam melakukan tatap muka karena ada pembatasan sosial 
dan juga menjaga jarak dengan orang lain. Subjek penelitian terdiri dari delapan orang mahasiswa semester enam yang menempuh mata kuliah ortodidaktik anak dengan gangguan emosi dan perilaku di salah satu universitas negeri di Yogyakarta.

\section{Teknik Pengumpulan Data}

Teknik pengumpulan data yang digunakan yakni observasi, wawancara, dan dokumentasi. Observasi digunakan untuk mengamati hasil identifikasi dan asesmen anak dengan gangguan emosi dan perilaku yang dipaparkan saat perkuliahan secara daring. Wawancara digunakan untuk mengumpulkan data mengenai kendala mahasiswa selama melakukan identifikasi dan asesmen. Dokumentasi digunakan untuk melihat data-data yang dikumpulkan oleh mahasiswa untuk proses identifikasi dan asesmen.

\section{Analisis Data}

Teknik analisis data yang digunakan yakni analisis deskriptif. Data-data penelitian yang telah dikumpulkan kemudian direduksi, didisplay, dan disimpulkan (Creswell, 2013). Tahapan-tahapan yang dilakukan dalam menganalisis data-data yang diperoleh yakni sebagai berikut:

a. Pengumpulan data-data dari mahasiswa yang telah melakukan identifikasi dan asesmen.

b. Mengamati hasil paparan dari mahasiswa mengenai hasil identifikasi dan asesmen pada anak dengan gangguan emosi dan perilaku.

c. Mengamati dokumen yang dikumpulkan oleh mahasiswa.

d. Mengumpulkan dari mahasiswa terkait kendala yang dialami selama melakukan identifikasi dan asesmen.

e. Membuat interpretasi dari data-data yang telah terkumpul.

\section{HASIL DAN PEMBAHASAN}

\section{Hasil}

Berdasarkan hasil wawancara dan observasi dengan delapan orang mahasiswa yang menempuh mata kuliah ortodidaktik anak dengan gangguan emosi dan perilaku, diperoleh data mengenai jumlah dan jenjang pendidikan dari anak dengan EBD yang diidentifikasi dan diasesmen oleh mahasiswa. Data tersebut ditampilkan pada Tabel 1 berikut ini:

Tabel 1. Jumlah dan Jenjang Pendidikan dari Anak dengan EBD

\begin{tabular}{cccll}
\hline \multirow{2}{*}{ No. } & $\begin{array}{c}\text { Mahasiswa } \\
\text { (Initial) }\end{array}$ & \multicolumn{2}{c}{ Anak dengan EBD } \\
\cline { 3 - 5 } & J & 1 & \multicolumn{1}{c}{ Jenjang } & \multicolumn{1}{c}{ Masalah yang Dimiliki } \\
\hline 1 & $\mathrm{~B}$ & 1 & Sekolah Danar-kanak (TK) & ADHD \\
2 & $\mathrm{C}$ & 1 & $\begin{array}{l}\text { Sekolah khusus (SD) } \\
\text { Sekolah luar biasa (SD) }\end{array}$ & $\begin{array}{l}\text { ADHD dan hambatan intelegensi } \\
\text { Gangguan perilaku dan autis } \\
\text { ingelegun perilaku dan hambatan }\end{array}$ \\
4 & $\mathrm{D}$ & 1 & Sekolah luar biasa (SD) & $\begin{array}{l}\text { Gangguan perilaku dan hambatan } \\
\text { intelegensi }\end{array}$ \\
5 & $\mathrm{E}$ & 1 & Sekolah luar biasa (SD) & $\begin{array}{l}\text { Gangguan perilaku dan hambatan } \\
\text { intelegensi } \\
\text { Gangguan perilaku dan hambatan } \\
\text { intelegensi }\end{array}$ \\
7 & F & 1 & Sekolah luar biasa (SD) & Gangguan perilaku \\
\hline
\end{tabular}

Berdasarkan Tabel 1, dapat diketahui bahwa mahasiswa melakukan identifikasi dan asesmen, masing-masing pada satu anak dengan EBD. Identifikasi dan asesmen dilakukan pada satu anak dengan EDB karena mata kuliah ortodidaktik yang ditempuh oleh mahasiswa merupakan mata kuliah yang mengajarkan mahasiswa untuk berlatih mengajar anak dengan EBD. Jadi, anak dengan EBD yang dijadikan sebagai subjek latihan berjumlah satu anak.

Identifikasi dan asesmen dilakukan pada anak dengan EBD yang berapa pada jenjang pendidikan taman kana-kanak (TK) dan sekolah dasar (SD). Jenjang TK terdapat satu anak dengan EBD, sedangkan jenjang SD terdapat tujuh anak dengan EBD. Pada jenjang SD, terdiri dari jenis pendidikan yang berbeda, yakni dua anak berada di sekolah inklusi dan lima anak berada di sekolah khusus. 
Hasil identifikasi dan asesmen juga menunjukkan kondisi yang beragam dari masing-masing anak dengan EBD. Masalah perilaku yang dimiliki oleh masing-masing anak dengan EBD antara lain, gangguan perilaku dan attention deficit hiperactive disorder (ADHD). Masalah perilaku yang dimiliki oleh anak dengan EBD juga disertai dengan kondisi lainnya, yakni hambatan intelegensi dan autis.

Selain data mengenai jumlah dan jenjang pendidikan dari anak dengan EBD yang menjadi subjek untuk identifikasi dan asesmen, berdasarkan hasil wawancara dan observasi diperoleh data mengenai bentuk kendala yang dihadapi mahasiswa selama melakukan identifikasi dan asesmen. Data tersebut ditunjukkan pada Tabel 2 berikut ini:

Tabel 2. Bentuk Kendala dalam Identifikasi dan Asesmen Anak dengan EBD

\begin{tabular}{|c|c|c|c|}
\hline No. & $\begin{array}{c}\text { Mahasiswa } \\
\text { (Initial) }\end{array}$ & Kendala & Alasan \\
\hline 1 & A & $\begin{array}{l}\text { a. Jarang bertemu anak secara } \\
\text { langsung } \\
\text { b. Jarang bertemu dengan orang tua } \\
\text { c. Jarang bertemu dengan guru } \\
\text { kelas }\end{array}$ & $\begin{array}{ll}\text { a. Adanya aturan untuk menjaga } \\
\text { jarak. } \\
\text { b. Sekolah masih menerapkan } \\
\text { belajar di rumah }\end{array}$ \\
\hline 2 & B & $\begin{array}{l}\text { a. Jarang bertemu anak secara } \\
\text { langsung } \\
\text { b. Jarang bertemu dengan orang tua } \\
\text { c. Jarang bertemu dengan guru } \\
\text { kelas }\end{array}$ & $\begin{array}{l}\text { a. Adanya aturan untuk menjaga } \\
\text { jarak. } \\
\text { b. Sekolah masih menerapkan } \\
\text { belajar di rumah }\end{array}$ \\
\hline 3 & C & $\begin{array}{l}\text { a. Jarang bertemu anak secara } \\
\text { langsung } \\
\text { b. Jarang bertemu dengan orang tua } \\
\text { c. Diminta guru untuk mengajar } \\
\text { anak }\end{array}$ & $\begin{array}{l}\text { a. Adanya aturan untuk menjaga } \\
\text { jarak. } \\
\text { b. Sekolah masih menerapkan } \\
\text { belajar di rumah } \\
\text { c. Pemahaman guru terkait tugas } \\
\text { mahasiswa }\end{array}$ \\
\hline 4 & D & $\begin{array}{l}\text { a. Jarang bertemu anak secara } \\
\text { langsung } \\
\text { b. Jarang bertemu dengan orang tua } \\
\text { c. Jarang bertemu dengan guru } \\
\text { kelas } \\
\text { d. Guru kelas mengerjakan tugas } \\
\text { lain }\end{array}$ & $\begin{array}{l}\text { a. Adanya aturan untuk menjaga } \\
\text { jarak. } \\
\text { b. Sekolah masih menerapkan } \\
\text { belajar di rumah } \\
\text { c. Adanya tugas tambahan guru }\end{array}$ \\
\hline 5 & $\mathrm{E}$ & $\begin{array}{l}\text { a. Jarang bertemu anak secara } \\
\text { langsung } \\
\text { b. Jarang bertemu dengan orang tua } \\
\text { c. Jarang bertemu dengan guru } \\
\text { kelas } \\
\text { d. Guru kelas mengerjakan tugas } \\
\text { e. Guin lupa memberi informasi }\end{array}$ & $\begin{array}{l}\text { a. Adanya aturan untuk menjaga } \\
\text { jarak. } \\
\text { b. Sekolah masih menerapkan } \\
\text { belajar di rumah } \\
\text { c. Adanya tugas tambahan guru }\end{array}$ \\
\hline 6 & $\mathrm{~F}$ & $\begin{array}{l}\text { a. Jarang bertemu anak secara } \\
\text { langsung } \\
\text { b. Jarang bertemu dengan orang tua } \\
\text { c. Jarang bertemu dengan guru } \\
\text { kelas } \\
\text { d. Guru kelas mengerjakan tugas } \\
\text { e. Guin lupa memberi informasi }\end{array}$ & $\begin{array}{l}\text { a. Adanya aturan untuk menjaga } \\
\text { jarak. } \\
\text { b. Sekolah masih menerapkan } \\
\text { belajar di rumah } \\
\text { c. Adanya tugas tambahan guru }\end{array}$ \\
\hline 7 & G & $\begin{array}{l}\text { a. Jarang bertemu anak secara } \\
\text { langsung } \\
\text { b. Jarang bertemu dengan orang tua } \\
\text { c. Jarang bertemu dengan guru } \\
\text { kelas }\end{array}$ & $\begin{array}{l}\text { a. Adanya aturan untuk menjaga } \\
\text { jarak. } \\
\text { b. Sekolah masih menerapkan } \\
\text { belajar di rumah }\end{array}$ \\
\hline
\end{tabular}




\begin{tabular}{ccllll}
\hline No. & $\begin{array}{c}\text { Mahasiswa } \\
\text { (Initial) }\end{array}$ & \multicolumn{2}{c}{ Kendala } & \multicolumn{2}{c}{ Alasan } \\
\hline 8 & $\mathrm{H}$ & a. & $\begin{array}{l}\text { Jarang bertemu anak secara } \\
\text { langsung }\end{array}$ & a. & $\begin{array}{l}\text { Adanya aturan untuk menjaga } \\
\text { jarak. }\end{array}$ \\
& b. & Jarang bertemu dengan orang tua & b. $\begin{array}{l}\text { Sekolah masih menerapkan } \\
\text { belajar di rumah }\end{array}$ \\
& c. & $\begin{array}{l}\text { Jarang bertemu dengan guru } \\
\text { kelas }\end{array}$ & & &
\end{tabular}

Berdasarkan Tabel 2, dapat diketahui bahwa ada beberapa bentuk kendala yang dihadapi mahasiswa dalam melakukan identifikasi dan asesmen pada anak dengan EBD. Bentuk-bentuk kendala yang dihadapi oleh mahasiswa dalam melakukan identifikasi dan asesmen pada anak dengan EBD antara lain yakni waktu yang terbatas untuk bertemu dengan anak dengan EBD, orang tua, dan guru. Selain itu juga, apabila mahasiswa bisa bertemu dengan guru kelas, maka kendala yang ada yakni mahasiswa diminta untuk mengajar anak dengan EBD, guru sedang mengerjakan tugas lainnya, dan guru lupa untuk memberikan data-data dalam bentuk dokumen yang terkait dengan identifikasi dan asesmen anak dengan EBD.

Kendala yang dihadapi oleh mahasiswa terjadi karena beberapa alasan antara lain yakni adanya aturan untuk menjaga jarak, sekolah masih menerapkan belajar dari rumah, pemahaman guru terkait tugas mahasiswa yang hanya melakukan identifikasi dan asesmen bukan mengajar, dan adanya tugas tambahan yang dimiliki guru sehingga tidak bisa memberikan pelayanan secara maksimal. Hal tersebut menjadi latar belakang penyebab dari keterbatasan mahasiswa dalam melakukan identifikasi dan asesmen terhadap anak dengan EBD.

Kendala yang dihadapi mahasiswa dalam melakukan identifikasi dan asesmen selama pandemi Covid-19 berdampak pada data-data yang dikumpulkan untuk identifikasi dan asesmen anak dengan EBD. Dampak adanya kendala dalam melakukan identifikasi dan asesmen pada anak dengan EBD ditampilkan pada Tabel 3 berikut ini:

Tabel 3. Dampak dari Kendala Identifikasi dan Asesmen Anak dengan EBD

\begin{tabular}{|c|c|c|c|}
\hline No. & $\begin{array}{c}\text { Mahasiswa } \\
\text { (Initial) }\end{array}$ & Dampak & Hasil \\
\hline 1 & $\mathrm{~A}$ & $\begin{array}{ll}\text { a. } & \text { Data yang dikumpulkan tidak lengkap } \\
\text { b. Kesulitan dalam menyimpulkan } \\
\text { kemampuan anak } \\
\text { c. Kesulitan dalam penyusunan program }\end{array}$ & $\begin{array}{l}\text { a. Program yang disusun belum } \\
\text { sesuai kondisi anak } \\
\text { b. Identifikasi dan asesmen } \\
\text { kembali } \\
\text { c. Kegiatan selanjutnya tertunda }\end{array}$ \\
\hline 2 & B & $\begin{array}{l}\text { a. Data yang dikumpulkan tidak lengkap } \\
\text { b. Kesulitan dalam menyimpulkan } \\
\text { kemampuan anak } \\
\text { c. Kesulitan dalam penyusunan program }\end{array}$ & $\begin{array}{l}\text { a. Program yang disusun belum } \\
\text { sesuai kondisi anak } \\
\text { b. Identifikasi dan asesmen } \\
\text { kembali } \\
\text { c. Kegiatan selanjutnya tertunda }\end{array}$ \\
\hline 3 & $\mathrm{C}$ & $\begin{array}{l}\text { a. Data yang dikumpulkan tidak lengkap } \\
\text { b. Kesulitan dalam menyimpulkan } \\
\text { kemampuan anak } \\
\text { c. Kesulitan dalam penyusunan program }\end{array}$ & $\begin{array}{l}\text { a. Program yang disusun belum } \\
\text { sesuai kondisi anak } \\
\text { b. Identifikasi dan asesmen } \\
\text { kembali } \\
\text { c. Kegiatan selanjutnya tertunda }\end{array}$ \\
\hline 4 & $\mathrm{D}$ & $\begin{array}{l}\text { a. Data yang dikumpulkan tidak lengkap } \\
\text { b. Kesulitan dalam menyimpulkan } \\
\text { kemampuan anak } \\
\text { c. Kesulitan dalam penyusunan program }\end{array}$ & $\begin{array}{l}\text { a. Program yang disusun belum } \\
\text { sesuai kondisi anak } \\
\text { b. Identifikasi dan asesmen } \\
\text { kembali } \\
\text { c. Kegiatan selanjutnya tertunda }\end{array}$ \\
\hline 5 & $\mathrm{E}$ & $\begin{array}{l}\text { a. Data yang dikumpulkan tidak lengkap } \\
\text { b. Kesulitan dalam menyimpulkan } \\
\text { kemampuan anak } \\
\text { c. Kesulitan dalam penyusunan program } \\
\text { d. Terlambat dalam mengumpulkan laporan }\end{array}$ & $\begin{array}{l}\text { a. Program yang disusun belum } \\
\text { sesuai kondisi anak } \\
\text { b. Identifikasi dan asesmen } \\
\text { kembali } \\
\text { c. Kegiatan selanjutnya tertunda }\end{array}$ \\
\hline
\end{tabular}




\begin{tabular}{|c|c|c|c|}
\hline No. & $\begin{array}{c}\text { Mahasiswa } \\
\text { (Initial) }\end{array}$ & Dampak & Hasil \\
\hline 6 & $\mathrm{~F}$ & $\begin{array}{ll}\text { a. } & \text { Data yang dikumpulkan tidak lengkap } \\
\text { b. Kesulitan dalam menyimpulkan } \\
\text { kemampuan anak } \\
\text { c. Kesulitan dalam penyusunan program } \\
\text { d. Terlambat dalam mengumpulkan laporan }\end{array}$ & $\begin{array}{ll}\text { a. Program yang disusun belum } \\
\text { sesuai kondisi anak } \\
\text { b. Identifikasi dan asesmen } \\
\text { kembali } \\
\text { c. Kegiatan selanjutnya tertunda }\end{array}$ \\
\hline 7 & G & $\begin{array}{l}\text { a. Data yang dikumpulkan tidak lengkap } \\
\text { b. Kesulitan dalam menyimpulkan } \\
\text { kemampuan anak } \\
\text { c. Kesulitan dalam penyusunan program } \\
\text { d. Terlambat dalam mengumpulkan laporan }\end{array}$ & $\begin{array}{l}\text { a. Program yang disusun belum } \\
\text { sesuai kondisi anak } \\
\text { b. Identifikasi dan asesmen } \\
\text { kembali } \\
\text { c. Kegiatan selanjutnya tertunda }\end{array}$ \\
\hline 8 & $\mathrm{H}$ & $\begin{array}{l}\text { a. Data yang dikumpulkan tidak lengkap } \\
\text { b. Kesulitan dalam menyimpulkan } \\
\text { kemampuan anak } \\
\text { c. Kesulitan dalam penyusunan program } \\
\text { d. Terlambat dalam mengumpulkan laporan }\end{array}$ & $\begin{array}{l}\text { a. Program yang disusun belum } \\
\text { sesuai kondisi anak } \\
\text { b. Identifikasi dan asesmen } \\
\text { kembali } \\
\text { c. Kegiatan selanjutnya tertunda }\end{array}$ \\
\hline
\end{tabular}

Berdasarkan Tabel 3, dapat diketahui bahwa kendala yang dihadapi mahasiswa dalam melakukan identifikasi dan asesmen pada anak dengan EBD berdampak pada aktivitas lainnya. Dampak yang muncul dari adanya kendala dalam identifikasi dan asesmen anak dengan EBD antara lain yakni data yang dikumpulkan terbatas/tidak lengkap, kesulitan dalam menyimpulkan kondisi anak, kesulitan dalam menyusun program yang sesuai dengan kondisi anak, serta ada juga mahasiswa yang terlambat dalam mengumpulkan laporan karena data yang dikumpulkan masih kurang sehingga perlu untuk melakukan pengumpulan data kembali. Dampak yang terjadi pada mahasiswa dalam melakukan identifikasi dan asesmen pada anak dengan EBD berpengaruh pada kinerja mahasiswa yakni program yang disusun oleh masiswa belum sesuai kondisi anak dengan EBD, melakukan identifikasi dan asesmen lagi, dan pelaksanaan kegiatan lainnya menjadi tertunda karena harus mengumpulkan data-data lagi.

\section{Pembahasan}

Berdasarkan hasil penelitian, dapat diketahui bahwa ada tiga temuan yang dibahas dalam penelitian yakni jumlah dan jenjang pendidikan anak dengan EBD yang diidentifikasi dan diasesmen, kendala yang dihadapi mahasiswa selama identifikasi dan asesmen, serta dampak yang muncul dari adanya kendala dalam identifikasi dan asesmen anak dengan EBD. Identifikasi dan asesmen yang dilakukan oleh mahasiswa terhadap anak dengan EBD, menyasar anak dengan EBD yang masih menempuh pendidikan, yakni anak dengan EBD di jenjang TK dan SD, baik sekolah inklusi atau sekolah khusus. Sesuai dengan yang diungkapkan oleh Kauffman \& Landrum (2018) bahwa identifikasi dan asesmen perlu dilakukan di lingkungan pendidikan terutama untuk mengetahui kondisi dari peserta didik. Identifikasi dan asesmen membantu pendidik dalam mengetahui peserta didik memiliki gangguan emosi dan perilaku atau tidak, mengetahui kemampuan yang dimiliki oleh peserta didik, dan layanan pendidikan yang dibutuhkan oleh peserata didik, terutama peserta didik dengan EBD (Kauffman \& Landrum, Characteristics of Emotional and Behavioral Disorders of Children and Youth: Eleventh Edition, 2018). Ketika pendidik bisa mengumpulkan data-data anak dengan EBD melalui identifikasi dan asesmen, maka pendidik akan lebih mudah mengetahui kondisi dari pesera didiknya. Berdasarkan kondisi peserta didik tersebut, pendidik bisa menentukan pengetahuan dan keterampilan yang akan diajarkan, media dan metode yang akan digunakan dalam pembelajaran, serta jenis evaluasi yang sesuai untuk melihat tingkat capaian dari peserta didik. Selain itu, guru juga perlu mengetahui masalah perilaku yang dimiliki oleh anak dengan EBD, karena penanganan anak dengan EBD tidak hanya pada akademiknya saja tetapi juga pada masalah perilaku mereka. Akademik dan penanganan masalah perilaku pada anak dengan EBD perlu dilakukan secara seimbang atau bersamaan karena ada keterkaitan antara keduanya (Shepherd, 2009). Masalah perilaku yang dimiliki anak dengan EBD dapat diketahui melalui functional behavior assessment (FBA). FBA membantu pendidik dalam mengetahui masalah perilaku yang dimiliki anak dengan EBD serta membantu dalam 
menetukan program atau teknik dalam menangani masalah perilaku yang muncul (Miltenberger, 2015).

Kendala yang dihadapi mahasiswa selama melakukan identifikasi dan asesmen antara lain yakni kurangnya waktu untuk bertemu dengan anak dengan EBD, orang tua, dan guru. Selain itu juga, apabila mahasiswa bisa bertemu dengan guru kelas, maka kendala yang ada yakni mahasiswa diminta untuk mengajar anak dengan EBD, guru sedang mengerjakan tugas lainnya, dan guru lupa untuk memberikan data-data dalam bentuk dokumen yang terkait dengan identifikasi dan asesmen anak dengan EBD. Kendala bisa terjadi dalam identifikasi dan asesmen pada anak dengan EBD. Sejalan dengan penelitian yang dilakukan oleh Kauffman, Mock, \& Simpson (2007) bahwa anak dengan EBD kurang teridentifikasi dan terlayani karena berbagai alasan. Kendala tersebut muncul seperti informasi yang diperoleh salah, adanya stigma yang melekat pada anak, dan penyangkalan yang muncul atas sikap negatif anak (Kauffman, Mock, \& Simpson, 2007). Hasil dalam penelitian ini juga sejalan dengan penelitian yang dilakukan oleh Landrum (2000) bahwa ada beberapa kendala saat melakukan identifikasi dan asesmen pada anak dengan EBD yakni kurang teridentifikasinya anak dengan EBD yang membutuhkan layanan, keterlambatan dalam melakukan identifikasi pada anak dengan EBD, dan adanya representasi yang berlebihan (Landrum, 2000).

Dampak yang muncul dari adanya kendala dalam identifikasi dan asesmen anak dengan EBD yakni data yang dikumpulkan terbatas/tidak lengkap, kesulitan dalam menyimpulkan kondisi anak, kesulitan dalam menyusun program yang sesuai dengan kondisi anak, serta ada juga mahasiswa yang terlambat dalam mengumpulkan laporan. Sejalan dengan penelitian yang dilakukan oleh Kauffman, Mock, \& Simpson (2007) bahwa identifikasi dan asesmen pada anak dengan EBD dapat mengalami permasalahan dalam pelaksanaannya. Kendala tersebut dapat berdampak seperti hanya sebagain kecil dari anak dengan EBD yang bisa menerima layanan pendidikan atau jenis perawatan tertentu, pelayanan yang diberikan tertunda, dan adanya konsekuensi negatif dari treatment yang diberikan atau penundaan treatment (Kauffman, Mock, \& Simpson, 2007).

Terdapat beberapa tinjuan pustaka mengenai beberapa dukungan yang bisa diberikan kepada individu berkebutuhan khusus selama pandemi Covid-19. Pertama tinjauan pustaka yang dilakukan oleh Redenius (2021) mengenai layanan siswa berkebutuhan khusus selama pademi Covid-19. Tinjauan pustaka tersebut menjelaskan bahwa pihak sekolah bisa mengintegrasikan strategi yang ada saat ini dengan literatur yang ada untuk mengelola perubahan sosial dan pendidikan selama dan setelah periode Covid-19. Beberapa strategi yang dijadikan contoh antara lain yakni penggunaan teknologi untuk menjangkau siswa dan keterkaitan emosional seperti pemberian dukungan belajar, membangun emosi yang positif, dan mebangun komunikasi dengan orang tua siswa (Redenius, 2021).

\section{KESIMPULAN}

Pembelajaran di tingkat perguruan tinggi terdiri dari beberapa kegiatan seperti penyampaian materi/pengetahuan, observasi lapangan, analisis kasus, pembuatan produk, sampai pada penilaian tingkat pemahaman mahasiswa. Kegiatan tersebut tentunya mengalami perubahan sesuai kondisi yang ada. Ada pandemi Covid-19 yang saat sedang dialami oleh memberikan dampak pada pelaksanaan kegiatan pembejaran terutama observasi kasus di lapangan. Salah satu kegiatan yang terkendala yakni kegiatan mahasiswa berupa identifikasi dan asesmen pada anak dengan EBD. Kendala yang dialami mahasiswa dalam melakukan identifikasi dan asesmen pada anak dengan EBD yakni kurangnya waktu untuk bertemu dengan anak dengan EBD, orang tua, dan guru. Selain itu juga, apabila mahasiswa bisa bertemu dengan guru kelas, maka kendala yang ada yakni mahasiswa diminta untuk mengajar anak dengan EBD, guru sedang mengerjakan tugas lainnya, dan guru lupa untuk memberikan data-data dalam bentuk dokumen yang terkait dengan identifikasi dan asesmen anak dengan EBD. Rekomendasi yang dapat diberikan yakni pendidik perlu mencoba beberapa strategi yang bisa membantu mahasiswa dalam mengumpulkan data-data di lapangan selama pandemi. Selain itu, penelitian selanjutnya dapat menemukan solusi yang bisa diterapkan untuk membantu mahasiswa dalam studi lapangan untuk memperdalam pemahaman pengetahuan yang mereka dapatkan selama pembelajaran.

\section{DAFTAR PUSTAKA}

Creswell, J. W. (2013). Research design: Qualitative, quantitative, and mixed methods approaches. United States of America: SAGE Publications. 
Gage, N. A., \& Lierheimer, K. (2012). Exploring Self-Concept for Students with Emotional and/or Behavioral Disorders as They Transition from Elementary to Middle School and High School. Education Research International, vol. 2012, Article ID 871984, 11 pages https://doi.org/10.1155/2012/871984.

Kauffman, J. M., Mock, D. R., \& Simpson, R. L. (2007). Behavorial Disorders, Vol 33, No 1, DOI:10.1177/019874290703300104.

Kauffman, J. M., \& Landrum, T. J. (2018). Characteristics of Emotional and Behavioral Disorders of Children and Youth: Eleventh Edition. New York: Pearson.

Kirk, S., Gallagher, J. J., Coleman, M. R., \& Anastasiow, N. (2009). Educating Exceptional Children: TWELFTH EDITION. United State of America: Houghton Miffl in Harcourt Publishing.

Landrum, T. J. (2000). Assessment for Eligibility: Issues in Identifying Students with Emotional or Behavioral Disorders. Assessment for Effective Intervention, 26(1), 41-49, doi:10.1177/073724770002600106 .

Miltenberger, R. G. (2015). Behavior Modification: Principles and Procedures: Sixth Edition. Boston: Wadsworth Publishing.

Redenius, T. (2021). Serving Students with Special Needs during COVID-19 Pandemic. Northwestern College, https://nwcommons.nwciowa.edu/education_masters/300/.

Shepherd, T. L. (2009). Working with Students with Emotional and Behavior Disorders : Characteristics and Teaching Strategies: International Edition. United State of America: Pearson Education.

Syamsi, I. (2016). Pelaksanaan Evaluasi Asesmen Akademik Siswa Tunalaras di SLB-E Prayuwana. Jurnal Pendidikan Khusus, Vol 12, No 1, DOI: https://doi.org/10.21831/jpk.v12i1.12837.

Whitcomb, S. A. (2018). Behavioral, Social, and Emotional Assessment of Children and Adolescents: Fifth Edition. New York: Routledge.

Xurvein, M. A. (2015). Assessment Process of EBD Students: Professional Perspectives. Sophia, the St. Catherine University repository website: https://sophia.stkate.edu/msw_papers/542.

Zionts, P., Zionts, L., \& Simpson, R. L. (2002). Emotional and Behavioral Problems: Handbook for Understanding and Handling Students. California: Corwin Press Inc.

\section{PROFIL SINGKAT}

Wening Prabawati, lahir di Tangerang, pada 22 April 1991. Pendidikan untuk tingkat Sekolah Dasar (SD) ditempuh di SD Negeri Semin 2 dan Sekolah Menengah Pertama (SMP) di SMP Negeri 1 Semin. Untuk tingkat Sekolah Menengah Atas (SMA) ditempuh di SMA Negeri 1 Wonosari. Setelah menyelesaikan Program Strata 1 di Universitas Negeri Yogyakarta, Fakultas Ilmu Pendidikan, Jurusan Pendidikan Luar Biasa pada tahun 2014, ia melanjutkan pendidikan pada Program Magister di Universitas Negeri Yogyakarta, Program Pascasarja, Program Pendidikan Luar Biasa dan lulus pada tahun 2017. Selama menempuh Program Magister, ia mulai bekerja sebagai tenaga pendidik di SD Muhammadiyah Ponjong pada tahun 2015. Selanjutnya pada tahun 2018, mulai bekerja sebagai tenaga pengajar di Universitas PGRI Yogyakarta pada Jurusan Pendidikan Luar Biasa, Fakultas Keguruan Ilmu Pendidikan. Kemudian pada tahun 2019, ia melanjutkan karirnya sebagai tenaga pengajar di Universitas Negeri Yogyakarta, Fakultas Ilmu Pendidikan, Jurusan Pendidikan Luar Biasa sampai dengan saat ini. 